\title{
Introduction of Innovative Teaching Platform for Rome's Micro-Urban Space in 18th Century Jian-wen HUANG ${ }^{1}$ and Ying $X U^{2, *}$
}

\author{
${ }^{1}$ School of Architecture and Urban Planning, Guangdong University of Technology. Guangzhou, \\ China. 510090 \\ ${ }^{2}$ Architectural Design and Research Institute, South China University of Technology, Guangzhou, \\ China. 510641 \\ ${ }^{*}$ Corresponding author
}

Keywords: Teaching platform, Micro-urban space, Vasi painting, Nolli map, City of Rome.

\begin{abstract}
The research team led by professor James Tice in Department of Architecture at University of Oregon has developed an innovative teaching platform "Imago Urbis: Giuseppe Vasi's Grand Tour of Rome". This network platform provides a geo-database map for the micro-urban space analysis to the eighteenth-century Rome by joining with two-dimensional Nolli Map and three-dimensional Vasi painting. The platform has used the modern information technology to link Nolli Map and Vasi painting, fully activated with more than 240 of Vasi paintings, including the measure, proportion, scale, sequence and structure of every building or landscape in the paintings, can become the important analyzing information for the building and landscape elements, which is great helpful to promote the teaching and research for the micro-urban space of Rome.
\end{abstract}

\section{Introduction}

The Italian architect Giambattista Nolli (1701-1756) published the first accurate scale map of Rome named La Pianta Grande di Roma (literally "the great plan of Rome") in 1748. Later this map was called the "Nolli map" and become a prototype of figure-ground maps helping people analyze the relationship between urban architecture and external space. And Nolli's contemporary Giuseppe Vasi (1710-1782), whose comprehensive documentation of the city and its monuments, especially in the document named Delle Magnificenze di Roma antica e moderna (literally "the splendors of ancient and modern Rome"), published from 1747-1761, establishes him as one of Rome's great topographers. Through careful observation within a pictorial tradition that relied on mathematical perspective, Vasi produced an amount of drawings for the urban space in Rome by engraving and etching, which was called "Vasi painting". By years of exploration and combining the works of the above two masters, the research team led by professor James Tice in Department of Architecture at University of Oregon, has developed an innovative teaching platform named "Imago Urbis: Giuseppe Vasi's Grand Tour of Rome" (Imago Urbis, literally "Image City").Through the opportunity to study at the Department of Architecture in the University of Oregon, we had a relatively close and preliminary understanding of Professor Tice's innovative teaching platform.

\section{Nolli Map: the Important Foundation of "Imago Urbis"}

The platform of "Imago Urbis" has an important previous achievement as the basis. This basis is the "Nolli Map", setting as the referencing map for the platform. In fact, the original "Nolli Map" was consisted of twelve beautifully carved copper plates. When the copper plates are assembled, the full size of integrated "Nolli Map" is six feet high and seven feet wide $(176 \mathrm{~cm}$ x $208 \mathrm{~cm})$. The map includes nearly 8 square miles of high dense cities and the surrounding rural terrain. It also identifies nearly 2,000 culturally significant sites. It was not only an extraordinary technical achievement at the $18^{\text {th }}$ century, but also represented a milestone in cartographic art and science. Using modern surveying techniques and satellite imagery to verify the "Nolli Map", people have 
confirmed the high accuracy of the map, even with errors within a very small range. The map has recorded the streets, squares, and public urban spaces of Rome in the $18^{\text {th }}$ century, including the interior details of hundreds of public buildings. The content in the map ensures its value as a unique historical document and allows later generations to see the most outstanding period of the ancient metropolis's center.

Since the original Nolli Map was the separated maps, Prof. Tice has carefully scanned and stitched them to make a complete and seamless high-resolution digital map, and established a digital window named "Nolli Map Engine 1.0" in the Interactive Nolli Map website (http://nolli.uoregon.edu) to run the digital map. Through the Map Engine, user can pan in any direction and zoom in to the city's macro scale or to the building's microscopic scale. The Map Engine also creates visual layers that focus on specific topics such as "City Walls", "Gardens", "Fountains", etc. These can be turned on and off, and are superimposed with the underlying Nolli Map to provide the best viewing condition. The Nolli map is not only the world's first accurate map of Rome city, but also an important foundation for the positioning and analyzing of other urban and architectural records of Rome in the 18th century.

\section{Vasi Painting: the Core Imprint of "Imago Urbis"}

Giuseppe Vasi was born in Sicily, Italy in 1710 and moved to Rome in 1736. Most of his adult life lived and worked in Rome. Vasi's most famous works were his paintings for the Rome city, a total of ten volumes of "Delle Magnificenze di Roma antica e moderna", which includes 241 pieces of copperplate paintings depicting Rome city. The classification of the ten volumes are: Volume I, Gates and Walls; Volume II, Piazze; Volume III, Major Churches and Basilicas; Volume IV, Palazzi and Streets; Volume V, the Tiber and its Bridges; Volume VI, Parish Churches; Volume VII, Monasteries; Volume VIII, Convents; Volume IX, Colleges and Hospitals; Volume X, Villas and Gardens. These paintings inherited and enhanced the traditional perspective way of painting, and carefully recorded and depicted the urban space and living scenes of Rome at that time. It is very important for the study of micro urbanism and the history of architecture in Rome.

Vasi painting was the cultural product of the "Grand Tour" era of Europe in the 18th century. "Grand Tour" began in the middle of the 17th century. At that time, the European young aristocracy rose to visit Europe and pay tribute to the historical heritage, which was called "Grand Tour". Rome has countless cultural treasures, historical monuments, fascinating scenery and warm climate. It is also a must-see place for Grand Tour. Since then, Italy appeared a group of artists who use the city painting as the theme of copperplate engraving. Due to the easy printing and dissemination, the copperplate paintings provided a attractive visual impression for travelers around the Europe. Vasi's "Delle Magnificenze di Roma antica e moderna" was the most popular printed matters at the time.

\section{Imago Urbis: the 21st Century Cooperation between Two Masters in the 18th Century}

Based on the investigation and observation, Prof. Tice's research team found that by using of modern geo-database technology, the works of two masters of Nolli and Vasi in the 18th Century can be efficiently integrated.

\section{Highly Matching between Vasi Painting and Nolli Map}

By compared with other contemporary maps, the Nolli map is the most useful map linked to the viewpoints of Vasi's paintings. Although the Nolli map is a two-dimensional plan and the Vasi paintings are three-dimensional perspective drawings, they both have accurate micro-urban space records and details showing all aspects of the city's daily life, not only from grand palaces to small solemn churches, but also from strict prison to quiet pawnshop. In most situations, Vasi's painting and Nolli's map can work together to provide a distinctive "navigation system" for every important 
urban heritage of Rome. This system not only fascinated the travelers in the $18^{\text {th }}$ century, but also inspired the imagination of the observers in the $21^{\text {st }}$ century.

Through the carefully positioning by Prof. Tice's team on "Imago Urbis" platform, the team discovered that there are 221 accurate positioning viewpoints of Vasi's "Delle Magnificenze di Roma antica e moderna" can be found in Nolli map. And more than 90 percent matching rate shows Vasi is a painter with more attention to record the whole city. By the red view point of Vasi's paintings showed on the "Imago Urbis" platform, the team indicated the frequency of interaction between the viewpoints of Vasi's paintings and the Nolli map. The "Imago Urbis" platform allows people to learn more about the ancient city of Rome, from maps to viewpoints, and from viewpoints to maps, to enable contemporary people to gain insights into the hidden context of Rome in the $18^{\text {th }}$ century, and even to re-imagine the city scenes that has been changed or completely disappeared.

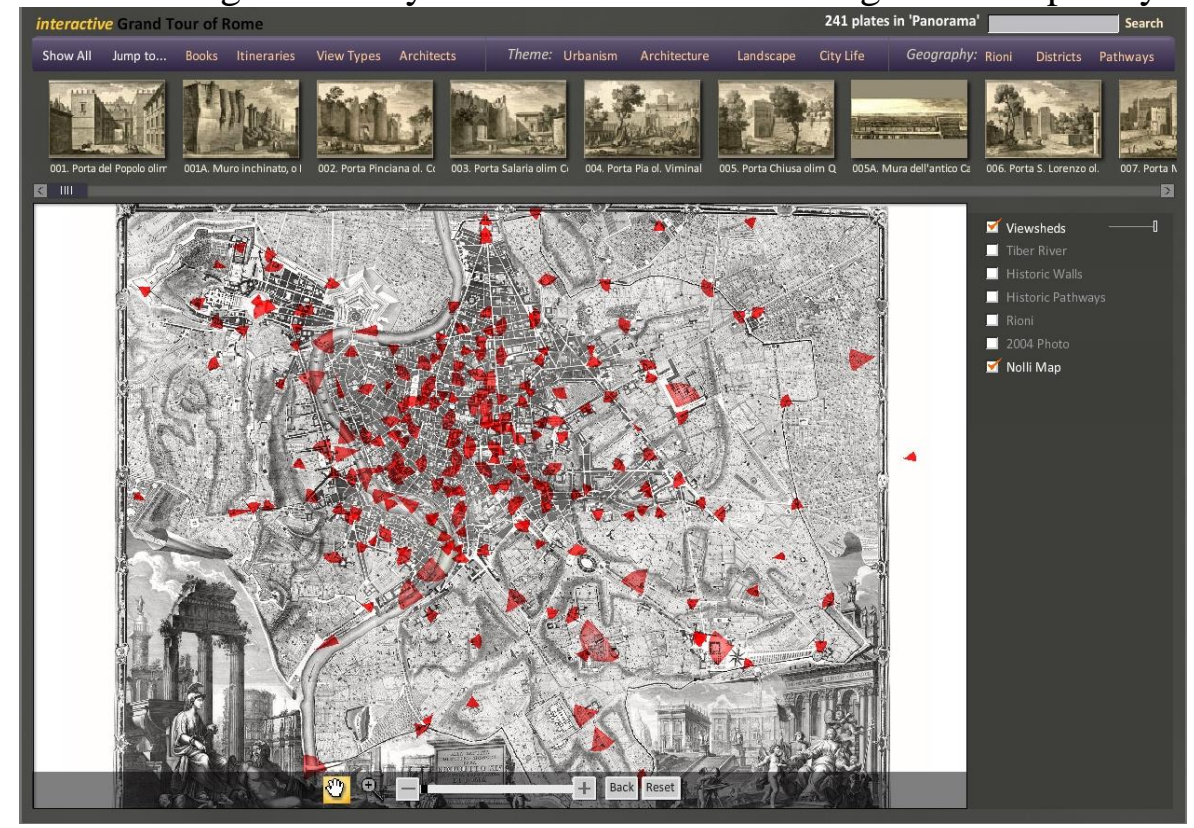

Figure 1. Nolli map as the basis of the viewpoints of Vasi's paintings (Source: http://vasi.uoregon.edu/)

\section{Vasi Painting Sort out the Cityscape System of Nolli Map}

Although Vasi's paintings belong to traditional styles and techniques like the landscape painting before his age, his dedication to faithfully documenting the city of Rome extended also to the carefully rendered entourages that populate his urban spaces. Just as he celebrates both major and minor buildings, and both celebrated and obscure piazze, so he also shows the poor alongside the rich. In the 18th century, a group of artists known for their traditional urban landscape paintings appeared in Rome, including Giovanni Battista Falda, Giovanni Paolo Panini, Claude-Joseph Vernet, and Giovanni Battista Piranesi. Each of them has formed his own unique vision of the cityscape. By comparing Vasi with his contemporary artists' works, "Imago Urbis" platform make the viewers pay attention to the choices of each artist's subjective selection in paintings by the point of view, composition and interpretation. For example, Piranesi, the disciple of Vasi, whose works are mainly interested in the magnificent sites and major monuments of Rome, compares Vasi with systematically recording various types of buildings throughout each of Vasi's ten volumes paintings. Characteristically, Vasi painting is dedicated to a specific category (city gates, churches, palaces, bridges, monasteries, villas, etc.), which can tell us about how the Romans provisioned their city and how they traversed the city.

\section{Vasi Painting Show the Anatomy of Micro-urban Space of Rome}

It is worth noting that when choosing architectural object for the painting, Vasi did not limit his viewpoint to isolated buildings, but instead not only included the adjacent buildings, but also the surrounding streets and squares, so that the entire urban environment and the accompanying 
complexity was presented. In addition, the accuracy of Vasi's urban painting is also worthy of attention, confirmed by modern field surveys (in the case of buildings still preserved), or by comparison with the careful survey of the Nolli Map and modern aerial photography, to further recognize the purpose of full display of micro-urban space of Rome. When the picture was resorted to distortion, such as the expansion of the street, his aim is to show more, not less, spatial elements through more "truthful" sense of the enveloping urban membrane rather than using an accurate perspective like photography. While some people may think that the perspective of certain painter, such as Piranesi, is even more striking in its dramatic city scene, the instructive paintings of Vasi actually having the architectural attributes can fully present the sense of the 18th century city's anatomy as a whole.

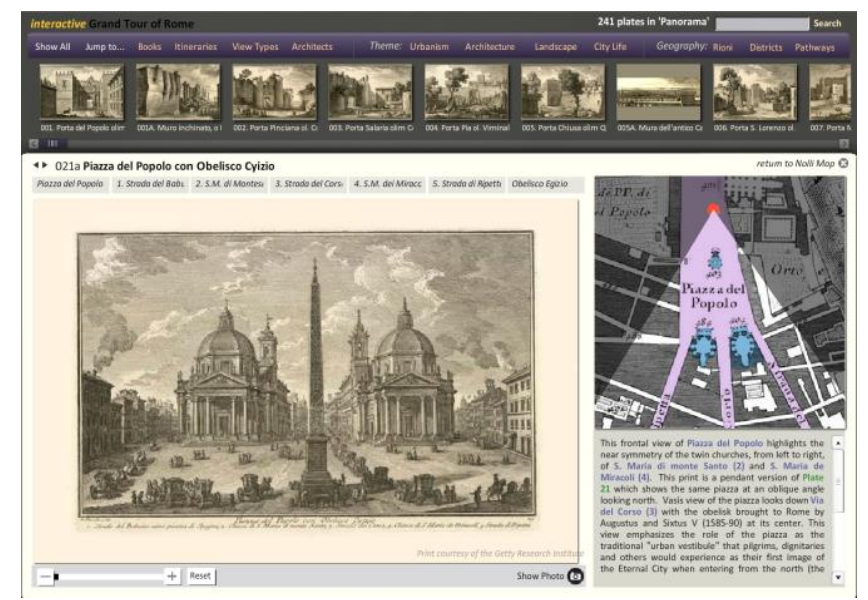

Figure 2. "Piazza del Popolo and obelisk of Egypt" of Vasi painting and Nolli map on "Imago Urbis" platform

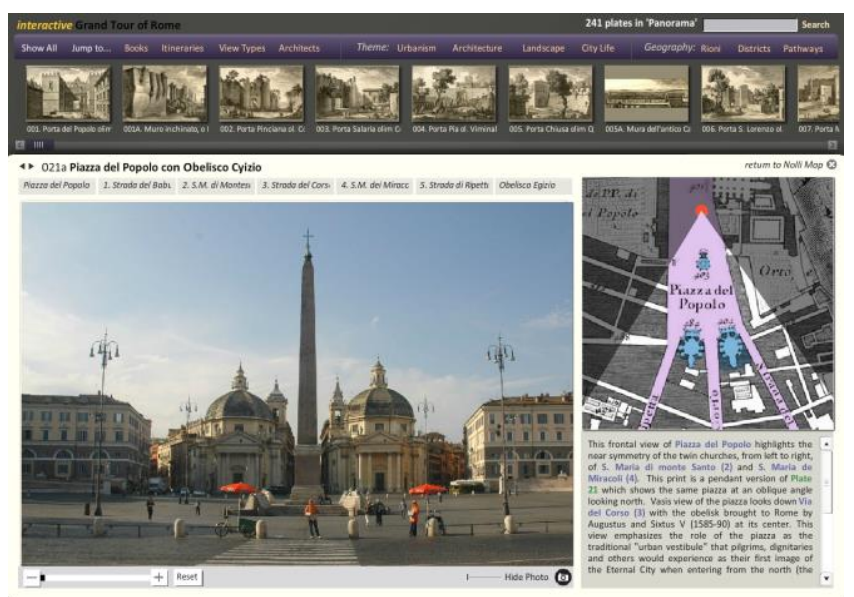

Figure 3. Same view of "Piazza del Popolo and obelisk of Egypt" by photograph

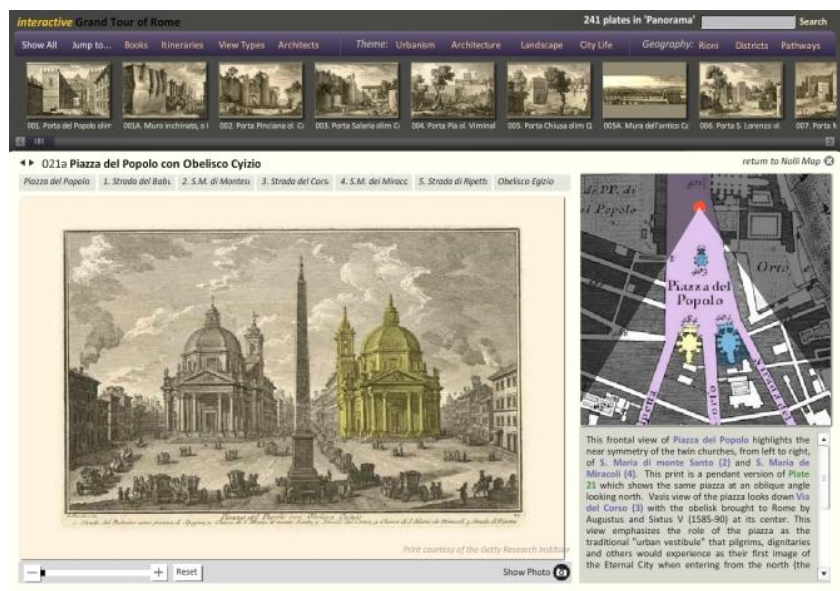

Figure 4. Important elements can be highlighted in Vasi painting and Nolli map 


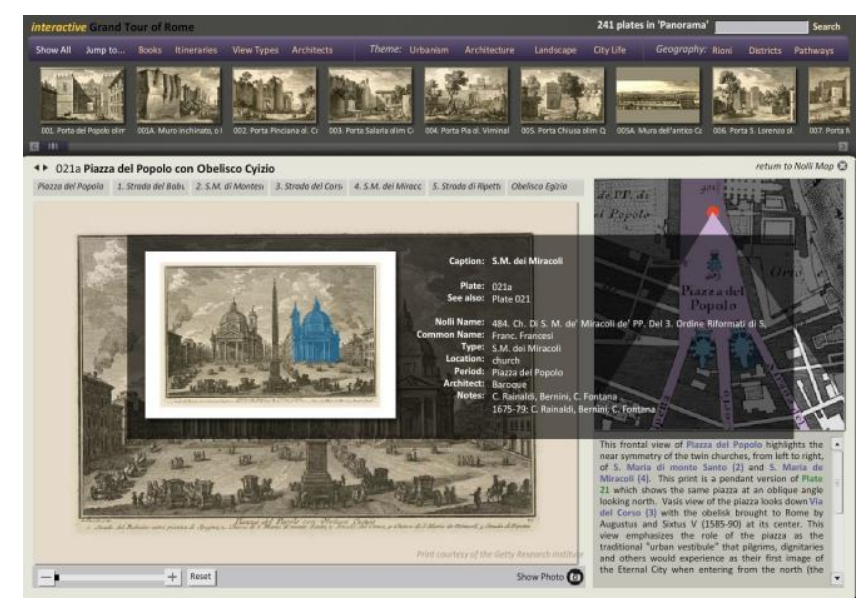

Figure 5. Relevant interpretations for the important elements

(Source of Figure 2-5: http://vasi.uoregon.edu/)

\section{Summary}

As the experienced teachers for teaching architecture at the University of Oregon, Prof. Tice' team has been studying the micro-urban space of Rome in the $18^{\text {th }}$ century for more than ten years. They hope to use modern geo-database technology to share their years of study for teaching and further research. The innovative teaching platform "Imago Urbis: Giuseppe Vasi's Grand Tour of Rome" is only an interim achievement and more study is ongoing, and it is a close 21 st century "collaboration" between two 18th century Masters Vasi and Nolli. And this intimate contact had become an important foundation for original research and outreach activities to celebrate Giuseppe Vasi's $300^{\text {th }}$ birthday in 2010.

The extensive combination of historical map, city paintings and modern geo-database technology, moreover with the rapid graphic imaging technology and the complex multimedia applications, will infinitely increase the attraction of historical documentations to young students and the public. Prof. Tice's successful experience leads us to believe that the new era of the public, especially young people, will increasingly embrace the interactive digital platforms on the network as the windows of learning, to see and understand the evolution of history and modern civilization. In addition, the innovative teaching platforms cannot be separated from interdisciplinary cooperation. The establishment of the "Imago Urbis" platform involves departments such as architecture, history, geography, and art history, combining new developments in sophisticated Information Science technology with new research on how 18th century Romans observed and documented their city, and bringing Vasi's Rome alive to 21 st century viewers.

\section{Acknowledgement}

We would like to thank Professor James Tice and his MappingRome team. This work would have not been possible without the expertise in continuing study of Rome from Professor James Tice and his team members.

This research was financially supported by the National Science Foundationof China (No. $51308130)$.

\section{References}

[1] Bowron E P, Joseph J R. Art in Rome in the Eighteenth Century [M]. Philadelphia: Merrell, 2000. 
[2] Ceen A. Introductory essay in Le Pianta Grande di Roma di Giambattista Nolli in Facsimile [M]. 2nd ed, New York: J.H. Aronson, Highmount, 1991.

[3] Coen P. Le magnificenze di Roma nelle incisioni di Giuseppe Vasi [M]. Rome: Newton Compton, 2006.

[4] Nick L, Peretti F, Fabbri G, et al. The Grand Tour: Landscape and Veduta Paintings [M]. Atlanta: Oglethorpe University Museum, 1997.

[5] Graves M. Roma Interotta [J]. Architectural Design, 1979, vol. 49: 1-104.

[6] Hockney D. Secret knowledge: rediscovering the lost techniques of the old masters [M]. New York: Viking Studio, 2001.

[7] Mead W E, The grand tour in the eighteenth century [M]. Boston and New York: Houghton Mifflin Company, 1914.

[8] Sassoli M G, Roma Veduta [M]. Rome: Artemide, 2000.

[9] Tice J, Erik S, Allan C. The University of Oregon Interactive Nolli Map Website [EB/OL]. University of Oregon. http://nolli.uoregon.edu/map/index.html.2005-01-01.

[10] Tice J, Erik S, Allan C, Beyer D. Imago Urbis: Giuseppe Vasi's Grand Tour of Rome [EB/OL]. University of Oregon. http://vasi.uoregon.edu/catalog/.2008-01-01. 